\title{
Information systems modeling
}

UDC 519.633.2

doi: 10.20998/2522-9052.2019.2.02

\author{
Y. A. Nasibov ${ }^{1}$, A. A. Bayramov², E. N. Sabziev ${ }^{3}$, E. G. Hashimov ${ }^{2}$ \\ ${ }^{1}$ Institute of Geography of Azerbaijan National Academy of Sciences, Baku, Azerbaijan \\ ${ }^{2}$ War College of Armed Forces of the Azerbaijan Republic, Baku, Azerbaijan \\ ${ }^{3}$ Institute of Control Systems of Azerbaijan National Academy of Sciences, Baku, Azerbaijan
}

\section{MODELLING OF THE RATIONALLY DEPLOYMENT OF OBSERVING SYSTEMS}

\begin{abstract}
The various types of electron-optical supervisory control systems (SCS) have been used in Armed Forces of many advanced countries. The mission of these SCS is to supervise day and night enemy troops, technics and weapon systems, frontier intruders with high precision a great and middle distance. The SCS optimal deployment in mountainous terrain makes possibility to use rationally SCS number, because SCS has very much costs. Using the rationally SCS number we can reduce a necessity of the specialist number. Also, it accelerates comander's correct decision making. The optimal deployment of SCS on a terrain is one of important task of military reconnaissance. The specific character of such task is that the necessary for continuing surveillance and control military objects can be located in specific zones of terrain (for examples, in canyons, along of river etc.). Accessible places of SCS set are situated on some distance from these zones. The number of SCS is limited; therefore, it is impossible to distribute theirs on the all set points. It is necessary to select such SCS set points that the zone observation range would be the largest. In present paper the mathematical model of the rationally deployment of technical observing systems in mountainous terrain has been developed and offered. The determination method of visibility level between selected terrain points has been developed. The assesment criterion of rationally deployment and the algorithm of fast solution have been offered.
\end{abstract}

Keywords : technical observing systems; mountainous terrain; rationally deployment; mathematical model.

\section{Introduction}

Nowdays, the various types of electron-optical supervisory control systems (SCS) have been used in Armed Forces of many advanced countries. With goal of optimal (rationally) SCS deployment in mountainous terrain by using of the digital altitude model of terrain the viewsheld analysis is possible to carry out [1-4]. The correct SCS deployment makes possibilities to take into account during monitoring such dead zones as runways or ravines. The correct SCS's posts selection increases the visible areas and, in the same time, decreases invisible areas and it helps us to eveal and to prevent enemy subversive actions.

The SCS deployment makes possibilities to take into account during monitoring such dead zones as runways or ravines. The correct SCS's posts selection increases the visible areas and, in the same time, decreases invisible areas and it helps us to eveal and to prevent enemy subversive actions. This SCS can be applied in civil goals, too: in war zone for security providing of oil pipeline, header water pipe, road infrastructure. The optimal deployment of SCS on a terrain is one of important task of military reconnaissance. The specific character of such task is that the necessary for continuing surveillance and control objects can be located in specific zones of terrain (for examples, in canyons, along of river etc.). Accessible places of SCS set are situated on some distance from these zones. The number of SCS is limited; therefore, it is impossible to distribute theirs on the all set points. It is necessary to select such SCS set points that the zone observation range would be the largest.

Analysis of rationally SCS deployment in mountainous terrain by using of the digital altitude model helps to select optimal points on the terrain. The SCS optimal deployment in mountainous terrain makes possibility to use rationally SCS number, because SCS has very much costs. Using the rationally SCS number we can reduce a necessity of the specialist number. Also, it accelerates comander's correct decision making. The SCS deployment makes possibilities to take into account during monitoring such dead zones as runways or ravines. The correct SCS's posts selection increases the visible areas and, in the same time, decreases invisible areas. The correct post's points and rational number deployment help to observe and to detect many targets and movements on the terrain. Also, it helps us to eveal and to prevent enemy subversive actions.

In present paper the mathematical model of the rationally deployment of technical observing systems in mountainous terrain has been developed and offered. The determination method of visibility level between selected terrain points has been developed. The assesment criterion of rationally deployment and the algorithm of fast solution have been offered.

\section{Some definitions}

For analysis, let us use the 3D digital vector model of the terrain relief. There is Digital Terrain Elevation Data (DTED) file in Fig. 1. We can see that this file has the values of elevations of the relief set in points of regular grid.

There are four neighbours around of each relief's points. For example, the points with knot's number of $(i-1, j),(i+1, j),(i, j-1)$ and $(i, j+1)$ are neighbours for point with knot's number of $(i, j)$. Let us denote the height of relief in knot of $(i, j)$ by $h(i, j)$, It is obvious, we can take such $0 x y z$ coordinate system that $\{(i, j)$, $(i \pm 1, j),(i \pm 2, j), \ldots\}$ knots set is located parallel to $O x$ 
axis for each $j$, and $\{(i, j),(i, j \pm 1),(i, j \pm 2), \ldots\}$ knots set is located parallel to $O y$ axis for each $i$, and $h(i, j)$ elevations are indicated along $0 z$ axis. The $0 x y$ plane included $h(i, j)=0$ points, and let us call it as basic plane.

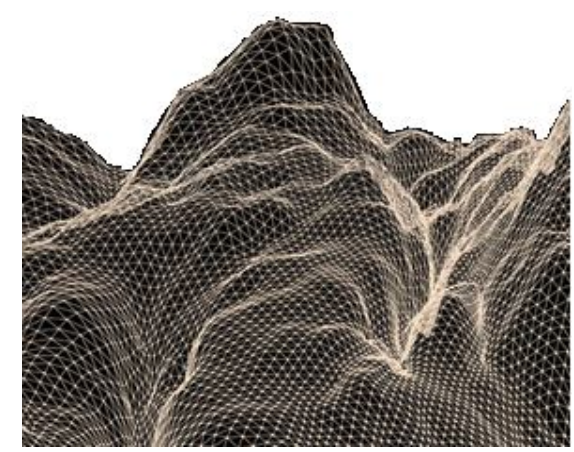

Fig. 1. 3D digital vector model of the terrain's relief

Neighbour's points are connected by straight lines, and in result, the 3D digital vector model of relief of the terrain is generated. These segments are called relief lines and their projections on side plane are called edges. All these edges can be divided on two classes. Let us consider if the first numbers of connected $(i, j)$, $(i \pm 1, j)$ knots of some edge are coincide then the this edge belongs to $P$ class. If the second numbers of connected $(i, j),(i, j \pm 1)$ knots of some edge are coincide then the this edge belongs to $M$ class.

Let $A$ and $B$ are some knots. Let $\operatorname{Pr}(A, B)$ is the projection of $A B$ segment on the $0 x y$ base plane. The edges set, the projection of which are crossed on the $\operatorname{Pr}(A, B)$, is called incidental.

Let us consider that for any $i, j$ the relief in range of space quadrangle with $(i, j),(i+1, j),(i+1, j+1)$, $(i, j+1)$ knots has such shape that any two points of its boundary edges can be connected by line not crossed on relief plane. So, we consider that always the knots see each other in range such space quadrangle.

\section{The task determination}

We consider that $3 \mathrm{D}$ map of terrain relief is presented in vector form, that is, for considered terrain the $h(i, j)$ heghts are set in $(i, j)$ knots. Let the necessary be search terrain's zones are known and connected to $(i, j)$ knots. Let us consider that the possible knots of SCS installation are marked. It is obvious, in the range of each observation place the most suitable observation point can be selected. For example, if the observation of nearest lowland is priority then the observation point can be placed nearer to observed points. However, if the observation of far lowland is priority then the observation point can be placed in highest point, etc. Therefore, we can adopt that observation points set is grouped around of $N$ separate high-altitude knots. Let they are called initial knots. In real conditions usually $N \leq 10$.

It is required to deploy $n(n<N)$ SCS on the terrain that they would provide the maximum observation zone. Not intersection the line segment connecting $A$ and $B$ points on the relief plane is condition of visibility $B$ point from $A$ point. That is, if $A B$ segment is placed above all incidental edges then $A$ point see $B$ point. The next method for solution this task is offered:
- development of $\wp$ procedure for the each other visibility checkup of two given knots;

- by application of $\wp$ procedure for each $A$ knot from the set of possible SCS deployment places to determine the set of visible and invisible points in range of technics possibilities of SCS;

- assessment of visibility level of zone and determination of the most suitable SCS deployment in the set of initial knots;

- improvement of computed solution by variation of knots in the range of group.

\section{Development of the $\wp$ procedure}

The task of investigation of $B$ point visibility from $A$ point can be turn into next subtasks:

(I) Determination of the incidental edges set;

(II) Assessment of the spatial deployment of $\mathrm{AB}$ segment and incidental edges.

Let us consider task (I). It is obvious, the incidental edges set can be presented in form of sets sum of incidental edges of $P$ and $M$ classes. Let mark these sets in $\mathcal{M}_{p}$ and $\mathcal{M}_{M}$ and forms. Let $A$ and $B$ knots have $\left(i_{A}, j_{A}, h_{A}\right)$ and $\left(i_{B}, j_{B}, h_{B}\right)$ coordinates, respectively, where $i_{A}, j_{A}, i_{B}, j_{B}$, are integer numbers.

Below there is an equation of the line connected $A$ and $B$ points on the $0 x y$ side plane $[5,6]$ :

$$
\frac{y-j_{A}}{j_{B}-j_{A}}=\frac{x-i_{A}}{i_{B}-i_{A}} \text {. }
$$

The coordinates of knots can be calculated on the base of equation (1). Let assume $j_{A} \neq j_{B}$. Let $\Delta_{y}=1$, if $j_{A}<j_{B}$, and $\Delta_{y}=-1$, if $j_{A}>j_{B}$. Denote the integer part of

$$
x_{j}=i_{A}+\left(\left(i_{B}-i_{A}\right) /\left(j_{B}-j_{A}\right)\right) \cdot\left(j-j_{A}\right),
$$

by $\beta(j)$. It is gotten from (1) when $y=j$. Then $\mathcal{M}_{p}$ set will be:

$$
\mathcal{M}_{p}=\left\{\left(\begin{array}{c}
{\left[\beta\left(j_{A}+k \Delta_{y}\right), j_{A}+k \Delta_{y}\right],} \\
{\left[\beta\left(j_{A}+k \Delta_{y}\right)+1, j_{A}+k \Delta_{y}\right]}
\end{array}\right], k=\overline{1, k_{y}}\right\},
$$

here:

$$
k_{y}=\left(j_{B}-j_{A}\right) / \Delta_{y} .
$$

If $j_{A}=j_{B}$ then $x_{j}=i_{A}$ and $\mathcal{M}_{p}$ set will be in form

$$
\boldsymbol{M}_{p}=\left\{\left(\begin{array}{c}
{\left[i_{A}, j_{A}+k \Delta_{y}\right],} \\
{\left[i_{A}+1, j_{A}+k \Delta_{y}\right]}
\end{array}\right), k=\overline{1, k_{y}}\right\} .
$$

Let assume $i_{A} \neq i_{B}$. Also, we take $\Delta_{x}=1$, if $i_{A}<i_{B}$, and $\Delta_{x}=-1$, if $i_{A}>i_{B}$. Denote the integer part of

$$
y_{i}=j_{A}+\left(\left(j_{B}-j_{A}\right) / i_{B}-i_{A}\right) \cdot\left(i-i_{A}\right),
$$

by $\alpha(i)$. It is gotten from (1) when $x=i$.

Then $\mathcal{M}_{p}$ set will be in form:

$$
\mathcal{M}_{p}=\left\{\left(\begin{array}{c}
{\left[i_{A}+k \Delta_{x}, \alpha\left(i_{A}+k \Delta_{x}\right)\right],} \\
{\left[i_{A}+k \Delta_{x}, \alpha\left(i_{A}+k \Delta_{x}\right)+1\right]}
\end{array}\right), k=\overline{1, k_{x}}\right\},
$$

here

$$
k_{x}=\left(i_{B}-i_{A}\right) / \Delta_{x} \text {. }
$$


If $i_{A}=i_{B}$ then $y_{j}=j_{A}$ and $\mathcal{M}_{M}$ set will be in form

$$
\mathcal{M}_{M}=\left\{\left(\begin{array}{c}
{\left[i_{A}+k \Delta_{x}, j_{A}\right]} \\
{\left[i_{A}, j_{A}+1\right]}
\end{array}\right), k=1,2, \ldots, k_{x}\right\} .
$$

The $\mathcal{M}$ set of all incidental edges will be a sum of the incidental edges of $P$ and $M$ classes, that is $\boldsymbol{M}=\boldsymbol{M}_{p} \mathrm{U} \boldsymbol{M}_{M}$. Now, let us consider task (II). First of all, let order elements of $\mathcal{M}$ set by serially number and dispose from $A$ to $B$ knots. Let incidental edges have numbers of $k=1,2, \ldots, k_{0}$. The coordinates of the crossing points of incidental edges on the (1) line are determined by (2) and (3) equations in dependence on class of its belonging. Let this point has $\left(x_{0}, y_{0}\right)$ coordinates. Let denote the knots coordinates of $k$ incidental edge by $\left(x_{k}^{\prime}, y_{k}^{\prime}\right)$ and $\left(x_{k}^{\prime \prime}, y_{k}^{\prime \prime}\right)$ respectively, and appropriate relief points by $\left(x_{k}^{\prime}, y_{k}^{\prime}, h\left(x_{k}^{\prime}, y_{k}^{\prime}\right)\right)$ and $\left(x_{k}^{\prime \prime}, y_{k}^{\prime \prime}, h\left(x_{k}^{\prime \prime}, y_{k}^{\prime \prime}\right)\right)$ respectively. Then, there is an equation of relief's line connecting these knots

$$
\frac{x-x_{k}^{\prime}}{x_{k}^{\prime \prime}-x_{k}^{\prime}}=\frac{y-y_{k}^{\prime}}{y_{k}^{\prime \prime}-y_{k}^{\prime}}=\frac{z-h\left(x_{k}^{\prime}, y_{k}^{\prime}\right)}{h\left(x_{k}^{\prime \prime} y_{k}^{\prime \prime}\right)-h\left(x_{k}^{\prime}, y_{k}^{\prime}\right)},
$$

and there is an equation of line connecting $A$ and $B$ peaks

$$
\frac{x-i_{A}}{i_{B}-i_{A}}=\frac{y-j_{A}}{j_{B}-j_{A}}=\frac{z-h_{A}}{h_{B}-h_{A}} .
$$

In concordance with above described method, there is not a visibility between $A$ and $B$ peaks if for some $k$ the line (4) in range of appropriate incidental edge will be located above the line (5).

Therefore, for clarification of visibility conditions between $A$ and $B$ peaks it is necessary to investigate for all $\mathrm{k}$ mutual alignment of these lines in indicated ranges.

Let denote the values of $z$ calculated in base point $\left(x_{0}, y_{0}\right)$ from (4) and (5), respectively, by $z_{r}^{k}$ and $z_{l}$. Then, it is obvious, there is not a visibility between $A$ and $B$ peaks if for any $k$ there is $z_{r}^{k}>z_{l}$. And there is a visibility between $A$ and $B$ peaks if for all $k=1,2, \ldots, k_{0}$ there is $z_{r}^{k} \leq z$.

\section{The criterion of the zone observability}

Let denote the set points of under obligatory observation terrain zones by $V_{0}$.

As stated above, the observation set points will be grouped around separate altitude knots of $A_{m}$ $(m=1,2, \ldots, N)$, which are taken as initial knots. Let $V_{m}$ are set knots, which can be observed from $A_{m}$ knot in the case of ideal flat relief, the ranges of which only are depended on technical characteristics of observation devices.

By use $\wp$ procedure for each initial knot of $A_{m}$ we will get $U_{m} \subseteq V_{m}$ sets.

The various tasks are set when devices are placed. Let consider two examples of these tasks.

Task 1. To deployment SCS such way that to embrace widest zone observation. In this case, we can take a following functional as the assessment criterion of zone observation range:

$\mathfrak{I}\left(m_{1}, m_{2}, \ldots, m_{n}\right)=\operatorname{mes}\left(\bigcup_{m=1}^{N} V_{m} / \bigcup_{k=1}^{n} \bigcup_{k}\right) \rightarrow \min$,

here: $m_{l}, m_{2}, \ldots, m_{n}$ are serial numbers of taken $A_{m}$ sets in number $n, \operatorname{mes}(L)$ is a measure of $L$ set.

As far as, all considered sets are limited and discrete then an operator mes $(L)$ is a number of elements of appropriate set.

Task 2. To deployment SCS such way that to embrace widest zone required observation. In this case, we can take a following functional as the assessment criterion of zone observation range:

$$
\Im\left(m_{1}, m_{2}, \ldots, m_{n}\right)=\operatorname{mes}\left(V_{0} \backslash \bigcup_{k=1}^{n} \bigcup_{m k}\right) \rightarrow \min .
$$

Thus, first of all, by application of $\wp$ procedure all sets included in functional are described. Then, by the method of $m_{1}, m_{2}, \ldots, m_{n}$ exhaustion, $\mathfrak{I}$ is calculated and the most suitable is determined. At this time, the number of all various observation devices on the initial peaks can be calculated as in combination $N$ with $n$ [7]:

$$
C_{N}^{n}=N ! /((N-n) ! n !),
$$

here: $N$ is a number of initial knots, $n$ is a number of observation devices. In real case, usually $N \leq 10$ and $n=3$ or 4 , therefore, at this stage the total number of calculations is $\leq 240$. Further, by varying knots in the range of $m_{1}, m_{2}, \ldots, m_{n}$ groups we can improve obtained solution. It is obvious, that from the point of view of mathematics it is possible to prove that in common case such algorithm not leads to potimal solution. However, in practice such solution is satisfactory. Therefore, this solution is called rationally.

\section{Conclusion}

So, it can be concluded:

- the mathematical model of the rationally deployment of technical observing systems in mountainous terrain has been developed and offered;

- the method of determination of the visibility between peaks points is developed;

- the criterium of assesment of the optimal deployment and the fast algorithm of task solution are offered.

\section{REFERENCES}

1. Nasibov, Y.A. (2014), "Geoinformation system, application areas and benefits", Herbi Bilik, 4, pp. 18-26.

2. Sabziev, E.N., Bayramov, A.A. and Nasibov, Y.A. (2018), "Modelling of the rationally deployment of technical observing systems in mountainous terrain", Proc. of the International Scientific Conference "Modern Problems of Mathematical Modeling, Computational Methods and Information Technologies", Rivne, Ukraine, 02-04 March, pp. 20-21.

3. Bayramov, A.A., Hashimov, E.G. and Nasibov, Y.A. (2018), "The supervisory control systems deployment in mountainous terrain", VIII Int. Conf. "Modern development trends of ICT and control methods", Poltava, Ukraine, 26-27 April, pp. 3-4. 
4. Nasibov, Y.A. and Bayramov, A.A. (2018), "The mountainous terrain digital elevation model making by GíS using", Abstract book. EURASIAN GIS 2018 Congress, 04-07 September, Baku, Azerbaijan. p. 61.

5. Beklemishev, D.V. (1987), Course of analytic geometry and linear algebra, Nauka, FIZMAT, Moscow, $320 \mathrm{p}$.

6. Kanatnikov, A.N. and Krishenko, A.P. (2000), Analytic geometry, MSTU after N.E. Bauman, Moscow, 388 p.

7. Erosh, E.L. (2001), Discrete mathematics. Combinatorics, SPbGUAP, Saint-Petersburg, 37 p.

Надійшла (received) 22.02.2019

Прийнята до друку (accepted for publication) 24.04.2019

\section{ВідОМОсті ПРО АвтOPIB / AвOUT THE AUTHORS}

Насібов Яшар Алі огли - науковий співробітник, Інститут географії Національної академії наук, Баку, Азербайджан; Yashar Ali Ogly Nasibov - research fellow, Institute of Geography of Azerbaijan National Academy of Sciences, Baku, Azerbaijan;

e-mail: yasharnasibli@yahoo.com; ORCID ID: http://orcid.org/0000-0002-8749-6154

Байрамов Азад Агалар огли - доктор фізико-математичних наук, професор, професор-радник, Військова академія Збройних Сил Азербайджанської Республіки, Баку, Азербайджан;

Azad Agalar ogli Bayramov - Doctor of Physics and Mathematics, Professor, Prof. Advisor, War College of Armed Forces of the Azerbaijan Republic, Baku, Azerbaijan; e-mail: azad.bayramov@yahoo.com; ORCID ID: http://orcid.org/0000-0001-6672-2338

Сабзісв Ельхан Наріман оглу - кандидат фізико-математичних наук, доцент, Інститут систем управління Національної академії наук Азербайджану, Баку, Азербайджан;

Elhan Nariman oglu Sabziev - Candidate of Physics and Mathematics, Associate Professor, Institute of Control Systems of Azerbaijan National Academy of Sciences, Baku, Azerbaijan;

e-mail: elkhan.sabziev@gmail.com; ORCID ID: http://orcid.org/0000-0001-8150-9439

Гашимов Ельшан Гіяс огли - кандидат технічних наук, професор, начальник відділу ад’юнктури та науки, Військова академія Збройних Сил Азербайджанської республіки, Баку, Азербайджан;

Elshan Giyas oğlu Hashimov - Candidate of Technical Sciences, Professor, Chief of department of Adjuncture and science, War College of Armed Forces of the Azerbaijan Republic, Baku, Azerbaijan;

e-mail: hasimovel@gmail.com; ORCID ID: http://orcid.org/0000-0001-8783-1277

\section{Моделювання раціонального розташування систем спостереження}

Я. А. Насібов, А. А. Байрамов, Е. Н. Сабзієв, Е. Г. Гашимов

Анотація. У збройних силах багатьох розвинених країн використовуються різні види електронно-оптичних наглядових систем (SCS). Призначення цих SCS полягає в цілодобовому точному контролі на близькому і далеких відстанях за військами супротивника, його технікою і озброєнням, а також за порушниками кордонів. Оптимальне розташування SCS в гористій місцевості сприяє можливості використовувати раціональну кількість SCS, тому що вартість SCS є дуже високою. Використовуючи раціональну кількість SCS можливо скоротити кількість необхідних фахівців. Це також скорочує час прийняття рішення командуванням. Оптимальне розташування SCS на місцевості є одним з важливих завдань військової розвідки. Специфічний характер цього завдання полягає в необхідності тривалого спостереження за військовими об'єктами, які можугь буги розташовані в особливих зонах на місцевості (наприклад, в каньйонах, уздовж русла річок тощо). Місця розташування SCS можуть розташовуватися на різних відстанях від цих зон. Кількість SCS обмежена, тому неможливо встановити їх на всіх обраних точках. Необхідно вибрати такі місця розташування SCS, щоб зона огляду була б максимальною. У даній статті пропонується розроблена авторами математична модель раціонального розташування технічних систем спостереження в гористій місцевості. Розроблено метод визначення рівня видимості між обраними точками на місцевості. Запропоновані критерії оцінки раціонального розміщення і алгоритм швидкого вирішення цього завдання.

Ключові слова: технічні системи спостереження; гориста місцевість; раціональне розміщення; математична модель.

\section{Моделирование рационального расположения систем наблюдения}

\section{Я. А. Насибов, А. А. Байрамов, Э. Н. Сабзиев, Э. Г. Гашимов}

Аннотация. В вооруженных силах многих развитых стран используются различные виды электронно-оптических наблюдательных систем (SCS). Назначение этих SCS заключается в круглосуточном точном контроле на близком и дальних расстояниях за войсками противника, его техникой и вооружением, а также за нарушителями границ. Оптимальное расположение SCS в гористой местности способствует возможности использовать рациональное число SCS, потому что стоимость SCS очень высока. Используя рациональное число SCS можно сократить число необходимых специалистов. Это также сокращает время принятия решения командованием. Оптимальное расположение SCS на местности является одним из важных задач военной разведки. Специфический характер этой задачи заключается в необходимости длительного наблюдения за военными объектами, которые могут быть расположены в особенных зонах на местности (например, в каньонах, вдоль русла рек и т.д.). Места расположения SCS могут располагаться на различных расстояниях от этих зон. Число SCS ограничено, поэтому невозможно установить их на всех выбранных точках. Необходимо выбрать такие места расположения SCS, чтобы зона обзора была бы максимальной. В данной статье предлагается разработанная авторами математическая модель рационального расположения технических систем наблюдения в гористой местности. Разработан метод определения уровня видимости между выбранными точками на местности. Предложены критерия оценки рационального размещения и алгоритм быстрого решения этой задачи.

Ключевые слова: технические системы наблюдения; гористая местность; рациональное размещение; математическая модель. 